\title{
THE TAGALOG LANGUAGE
}

Tagalog is a language spoken by an estimated 48 per cent of the approximately thirty million inhabitants of the Republic of the Philippines, a country composed of more than 7, UUV islands off the coast of South Asia in the Western Pacific. It is spoken mostly by people from the central part of Luzon, the Philippines' largest island. In addition to Tagalog, there are anywhere from 80 to 150 other languages in the Philippines (depending on how one applies the concepts dialect and language), all of which belong to the Malayo-Polynesian family. The most important of the se are Tagalog, Cebuano, Ilo kano, Hiligaynon, Bikol, Pampango, Waray, and Pangasinan.

Tagalog is spoken by about thirteen million Filipinos, natively by about eight million and as a second language by an additional five million people from the other parts of Luzon and other islands, who also have their own native languages. Tagalog is transmitted to these other places as a second language by various means, such as contact with native Tagalog speakers, through Tagalog movies and radio programs, and in the schools. But in spite of the gradual dissemination of Tagalog among nonTagalog speakers, the mutual non-intelligibility of the other languages remains.

Because of this diversity of tongues, the need for a national language has iong been felt. In 1435 , when it was promulgated during the Commonwealth Period, the Constitution of the Fhilippines included a provision for the adoption of a national language based on one of the existing native languages. The need for linguistic research to determine the appropriate basis of a national language resuited in the creation of the Institute of National Language in 1936 by Commonwealth Act 184. One year later the Institute officialiy chose Tagalog as the basis of the national language.

In 1959 , it was decided that the national language should be known officially as Pilipino in the schools. It is Tagalog enriched with officially recognized borrowings (from other Philippine languages and from Spanish, English, and Chinese), coinages, and revived words, which have had varying degrees of success in popuiar usage. Standardized grammar rules and spellings along with officially adopted lexical items have been promulgated from time to time for Pilipino, which do not necessarily affect Tagalog.

Beginning Tagalog is a Tagalog textbook. For student purposes, the difference between Pilipino and Tagalog might best be described in terms of style and formality, in somewhat the way we can distinguish between the "For whom is this?" type of English and the "Who is this for?" type. Tagalog, the Philippine "Who is this for?" type, has been purposely chosen rather than Pilipino, since it is the purpose of this text to prepare the student for an informal, inconspicuous, and native-like, rather than for a formal, noticeable, and schoollike, control of the language. 